\title{
Uzdasi u poodmakloj dobi - Petrarca, Vinci, Wert i Marenzio
}

\section{Sighs in Advancing Years - Petrarch, Vinci, Wert and Marenzio}

Ključne besede: Petrarca, madrigal, retorika, kadenčne sheme, vodenje glasov

\section{IZVLEČEK}

Petrarcov sonet "Se la mia vita da l'aspro tormento«, $v$ katerem pesnik izpoveduje upanje, da mu bodo pozna leta prinesla pogum za priznanje dolgo potlačenih čustev do svoje ljubljene, je podan v enem stavku. Predstavljene uglasbitve treh skladateljev 16. stoletja - Pietra Vincija, Giaches de Werta in Luce Marenzia, ga uresničujejo na različne načine. Vinci pod vplivom moteta uporablja zadržan stil, Wert se nad Petrarcovimi namigi blede lepote in poznimi leti navdušeno odziva $z$ domiselno simbolično shemo kadenc, medtem kot Marenzio, reagirajoč na takratno modo, izbira teksturo, v kateri si vsi štirje glasovi delijo spevne fraze. $S$ takšnim načinom je Marenzio upočasnil tempo govora in ni dosegel intenzitete s katero se je Wertu uspelo povzdigniti $\mathrm{k}$ izzivom Petrarcove poezije.
Keywords: Petrarch, madrigal, rhetoric, cadential schemes, voice-leading.

\section{ABSTRACT}

Petrarch's sonnet "Se la mia vita da l'aspro tormento «, in which the poet is expressing the hope that advanced age will bring him the courage to admit to his lady his long suppressed feelings, is conceived as a single sentence. The three sixteenthcentury composers whose settings are discussed - Pietro Vinci, Giaches de Wert and Luca Marenzio, approach their tasks differently. Vinci employs a reserved, motet-influenced style, Wert delights in responding to Petrarch's suggestion of the waning beauty and advancing years with an ingenious symbolic scheme of cadential points, while Marenzio, reacting to the current fashion, opts for a texture in which singable phrases are shared by all four voices. In so doing, Marenzio slows down the pace of delivery and does not quite come up to the intensity with which Wert manages to rise to the challenges offered by Petrarch.

Ako postoji bilo kakva konstanta u poetskome ukusu šesnaestoga stoljeća, onda je to Petrarkina poezija. Od mantovanske frottole na početku cinquecenta, do manirističkih kromatskih eksperimenata na kraju toga stoljeća, pjesnici su u rukama kompozitora dobivali ili gubili na popularnosti, pa je čak i Petrarca u zadnjim godinama stoljeća morao ustuknuti pred epigramatskim poetskim madrigalima Tassovim i Guarinijevim. Činjenica je da je Petrarca gotovo uvijek predstavljao svojevrsni izazov, te da su, kada su posezali za njegovim tekstovima, kompozitori shvaćali da se radi o poeziji koja i svojim sadržajem i svojim formalnim osobitostima zahtijeva od njih izuzetnu pažnju. 
Među polifonim madrigalima nije rijetko naići na neke, po poetskoj formi uglavnom sonete, koji su, jednom uglazbljeni od kompozitora jedne generacije, postajali uzor ili izazov njihovim mlađim kolegama. Imitacija kao vid laskanja bila je udomaćena i kod rimskih klasika, a renesansni pjesnici i kompozitori su oduševljeno prihvatili ovaj način iskazivanja pažnje starijim majstorima, često ga kombinirajući sa nadmetanjem, nastojeći da po nečemu nadmaše ili promijene uzor kojega oponašaju. Takav ikonički status postigli su, na primjer, »Ite, caldi sospiri« (RVF 153) ili »Or che 'l ciel« (RVF 164). ${ }^{1}$ Sonet "Se la mia vita" $(R F V 12)$, nije dostigao popularnost koja bi se s ovima mogla mjeriti, a o razlozima za to možemo samo nagađati. Ipak se tokom šesnaestoga stoljeća našlo nekoliko madrigalskih verzija ovoga soneta, bilo da se radilo o ranijim verzijama kod kojih su Girolamo Scotto i Francesco Bifetto iskoristili samo prvih osam stihova ili o verzijama koje, dijeleći tekst na Prima i Seconda parte, koriste svih četrnaest stihova. Nešto više od četrdeset godina dijeli najraniju zabilježenu verziju Girolama Scotta od Marenzijeve:

$\begin{array}{llll}1541 & \text { Girolamo Scotto } & \text { Novo izdanje: } 1562 . & \text { Troglasni } \\ 1548 & \text { Francesco Bifetto } & & \text { Četveroglasni } \\ 1554 & \text { Francseco Portinaro } & & \text { Peteroglasni } \\ 1561 & \text { Pietro Vinci } & \text { Nova izdanja: } 1563,1564,1566,1589 . & \text { Peteroglasni } \\ 1564 & \text { Francesco Menta } & \text { Sacuvan bez dionice basa. } & \text { (Peteroglasni) } \\ 1567 & \text { Giaches (Iaches) de Wert } & \text { Nova izdanja: } 1568,1583 . & \text { Peteroglasni } \\ 1588 & \text { Luca Marenzio } & & \text { Četveroglasni }\end{array}$

Bez obzira na umjetničke vrijednosti pojedinih verzija, iz statističkog se pregleda dade vidjeti da su Vincijeva i Wertova verzija bile popularnije od drugih. Scotto je, naravno, bio popularan jedno vrijeme oko sredine stoljeća, ali je njegov stil ubrzo postao prejednostavan i preskroman po izražajnim vrijednostima da bi njegovim madrigalima osigurao popularnost u drugoj polovici stoljeća. Vincijeva popularnost je pomalo iznenađujuća jer se radilo o kompozitoru s juga Italije, a ovi su često kaskali iza svojih kolega iz sjevernijih centara. Wertova popularnost u vrijeme novih izdanja bila je nedvojbena, ali je zanimljivo da je Marenzijeva Primo libro de' madrigali a quattro, cinque e sei voci ostala jedina od njegovih mnogobrojnih zbirki koja nikada nije doživjela novo izdanje i po tome se oštro izdvaja od ostaloga repertoara ovoga, pred kraj cinquecenta najpopularnijega madrigaliste. Možda je previše pozitivistički samouvjereno nadati se da bi jedna analiza nekolicine verzija ovoga madrigala mogla rasvijetliti ovu anomalju, ali je izazov ovoga pitanja sam po sebi toliko jak da je vrijedno pokušati i odazvati mu se.

U samoj je poeziji Petrarkinoj već sadržan izazov kompozitoru, a taj je osobito jak u slučaju soneta »Se la mia vita«. Sonet pripada jednome tipu, zastupljenome pretežno u drugome dijelu RVF (In morte di madonna Laura), a manje u prvome (In vita) - radi se o tvorevinama koje predstavljaju poetski i retorički tour de force i sastoje se iz jedne jedine rečenice:

1 U ovome eseju za Petrarkin Canzoniere upotrijebljen je naziv Rerum vulgarium fragmenta (skraćenica RVF), što ga je svojoj zbirci dao sâm pjesnik. Svi tekstovi na talijanskome originalu citirani su po: Francesco Petrarca, Canzoniere, edizione commentata a cura di Marco Santagata. Milano: Arnoldo Mondadori Editore, 1996. Hrvatski prepjevi citirani su po izdanju: Francesco Petrarca, Kanconijer, priredio Frano Čale. Zagreb-Dubrovnik: Liber, 1974. 
Se la mia vita da l'aspro tormento si può tanto schermire, et dagli affanni, ch'i' veggia per vertù degli ultimi anni, donna, de' be' vostr'occhi il lume spento,

e i cape' d'oro fin farsi d'argento, et lassar le ghirlande e i verdi panni, e 'l viso scolorir, che ne' miei danni allamentar mi fa pauroso et lento:

pur mi darà tanta baldanza Amore, ch'i' vi discovrirò de' mei martiri qua' sono stati gli anni, e i giorni, et l'ore;

et se 'l tempo è contrario ai be' desiri, non fia ch'almen non giunga al mio dolore alcun soccorso di tardi sospiri.
Ako se život moj od patnje ljute mogne toliko branit, i od sjete, pa uzvidim, kad godine odlete, da vam se, gospo, sjajne oči mute,

i da vam srebre kose zlatožute, da haljine nisu mlade, ni pram spleten, da blijedi lice što me, plaha, smete

8 kad jadikujem usred boli krute, tad će mi Amor takvu smjelost dati da ću vam otkrit svoje muke velje 11 godina dugih, i dana, i sati;

pa bude l' dob ta protiv ljuven želje, bar će mi tugu dostići na kraju

14 pomoć u nekom kasnu uzdisaju.

(preveo M. Maras)

Pozicija ovoga soneta, pri samome početku $R V F$, navodila je prijašnje komentatore (napr. Ezio Chiorboli) da ga smjeste u rani, avignonski pjesnikov period, ali za to nije bilo nikakvih drugih ubjedljivih razloga. Vittore Branca i Marco Santagata, primjenjujući tekstovnu i skripturalnu analizu, sugerirali da se radi o sonetu koji je mogao nastati negdje oko godine 1352, te koji doista i odgovara sentimentima starijega pjesnika, a nije samo projiciranje u budućnost onoga što bi jedan mladi zaljubljenik mislio da ga u poodmaklim godinama čeka. ${ }^{2}$ Sonet je, uz to, po poetskim slikama i jeziku blizak jednoj grupi kasnih soneta ( $R V F 315-317)$ koji dalje razvijaju misli prvi put naslućene u $R V F 12$. Osobito stihovi 9-12 iz RVF 315 ("Tutta la mia fiorita et verde etade«):

Presso era 'l tempo dove Amor si scontra con Castitate, et agli amanti è dato sedersi insieme, et dir che lor incontra.
Bližila dob se kada Amor sretne Nevinost, kad zaljubljenim dade sjedit i zborit što im na um pade.

(preveo M. Maras)

kao da opisuju i situaciju u kojoj bi moglo doći do komuniciranja toga »kasnog uzdisaja«, one slike s kojom je bio završio sonet $R V F 12$.

Ni jednoga časa ne slabi pjesnikov intenzitet u ovome sonetu. Zbog želje da ga uobliči kao jednu rečenicu, Petrarca upotrebljava kompleksnu sintaksu, kojom postiže da se očekivanje probuđeno smislom prvih stihova odgađa. Tek na samome kraju soneta nailazimo na potpuno ispunjenje te naslućene i stalno odgađane mogućnosti. Ponegdje u pjesmama iz RVF možemo razlikovati autorski i neki drugi glas, nagovješćuju se mogućnosti dijaloga, koje su kompozitori i te kako spretno znali iskoristiti. Ta dijaloška situacija ne postoji u RVF 12 - jedan se te isti glas čuje u neprekinutome monologu i tek na jednome mjestu, 
na formalnome početku drugoga dijela soneta, u stihu 9, "pur« nagovještena je realizacija modalnoga značenja koje je sadržano u početnoj riječi: »Se«. Već ta neprekidnost - užurbani govor - dočarava situaciju u kojoj onaj koji je svoja osjećanja dugo tajio sada konačno uspijeva smoći dovoljno hrabrosti, pa izgovara čitav svoj monolog užurbano, u jednome dahu. Bilo bi previše očekivati da će svaka madrigalska verzija na koju naiđemo u podjednakoj mjeri u muzičkome slogu ispuniti izazove koje kompozitoru postavlja pjesnik. U nekim svojim ranijim radovima na ovu temu, bio sam već zagovarao pristup pomoću kojega možemo, ako ne drugo, a ono pokušati da se približimo mentalnome procesu jednoga kompozitora u času u kojem se on obraća svome poetskom uzoru prvenstveno kao čitalac. ${ }^{3}$ Ostatak ovoga eseja je posvećen sličnome pokušaju.

Slijedeći uobičajeno pravilo da kompoziciji koja svojim tekstom sugerira teme tugovanja, patnje ili trpljenja, najviše odgovara drugi (frigijski) par modusa, Pietro Vinci (oko 1525 - oko 1584), najstariji od tri kompozitora čije su verzije razmatrane ovdje, sasvim predvidljivo poseže za frigijskim načinom. Na to ga navode concetti chiave u RVF 12: »tormento«, »lamentar«, "martiri«, »dolore«. Još u Josquinovoj generaciji ustalila se veza između tragične tematike teksta i frigijskog načina, a najčuveniji primjeri toga postupka su svakako Josquinov »Miserere mei Deus« i Isaacova tužbalica povodom smrti Lorenza de’ Medici, »Quis dabit capiti meo aquam«. Već se i kod njih očituje harmonska labilnost koja traje tokom čitavoga cinquecenta kad god se radi o frigijskome načinu - tkivo kompozicije koleba se između kadenci frigijskoga načina (na E) i tada novoga, eolskoga načina (na A). Vinci tako, pošavši od izričito frigijske melodijske konture na početku svoga madrigala, završava njegov prvi dio kadencom na A, ali se na kraju Seconda parte ipak vraća E-modusu. Godine 1561, u vrijeme kada je Vinci objavio zbirku u kojoj se ovaj madrigal nalazi, u Willaertovim i Roreovim madrigalima česti su melodijski pomaci i harmonske osobitosti kojima se žele naglasiti dramatične crte poetskog teksta. Vinci je u to vrijeme bio još uvijek ponešto provincijski muzičar, tek oko 1560. došavši u dodir sa muzikom jednoga većeg centra, Napulja, nakon svoje mladosti provedene na Siciliji. Ti prvi dodiri sa nešto smjelijim slogom nagoviješteni su iznenadnim kromatskim pomacima, poput onoga između $d$ i cis u konturi početne fraze madrigala, ali mogućnosti naslućene ovim pomakom nisu realizirane i u harmonskome slogu. Tu i tamo pojavi se po koji pomak $a-b$, također bez većih posljedica. Čitav tok madrigala podsjeća na nizanje imitativnih početaka karakterističnih za strukturu onovremenog moteta, u što spada i relativna bliskost imitativnih motiva kojima počinju Prima i Seconda parte (Pr. 1).

\section{Pr. 1, Vinci, "Se la mia vita«:}

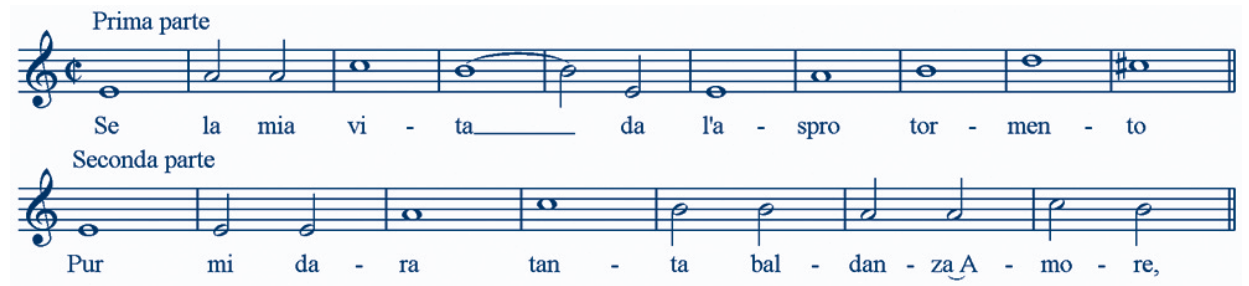

3 Vidi B. Bujić, „Palestrina, Willaert, Arcadelt and the Art of Imitation «, Recercare, X (1998), 105-131; ”Cinquecento Madrigalists as Readers of Poetry«, u Music, Words, and Images. Essays in Honour of Koraljka Kos, ur. Vjera Katalinić i Zdravko Blažeković. Zagreb, 1999, 13-26. 
»Ozbiljnost« Vincijeva pristupa odražava se i u suzdržanosti s kojom on pristupa bilo kakvome tonskom slikanju. Za madrigale nastale u ovo vrijeme, početkom sedme decenije stoljeća, sasvim je prirodno da sadrže različite predvidljive melodijske obrasce, a kasnije, kako ćemo vidjeti, Marenzio nije mogao odoljeti iskušenju da na riječ "ghirlande« razvije jedan melizmatski niz. Vinci je i po ovome još provincijalac - pitanje čitanja i potenciranja poetskih slika putem melodijskih obrazaca kod njega je još uvijek ograničeno elementarnim motetskim stilom i svodi se na minimalne natruhe: tek na jednome mjestu, i to u dionici drugoga alta (Quinto), pojavljuje se jedna kratka melizma od četiri osminke na "ghirlande«, ali i ta unutar kontrapunktske konstrukcije koja se često sreće u motetskoj literaturi i na mjestima koja ne zahtijavaju nikakvo tonsko slikanje. Vincijeva udaljenost od literarnih centara sjeverne Italije, u kojima se vjernost poetskome tekstu sve više smatrala sastavnim dijelom odgovornosti jednoga muzičara kao člana humanističke zajednice literata i kompozitora, pokazuje se i u njegovome odnosu prema poetskome tekstu. Posljednji Petrarkin stih glasi u Vincija: »alcun soccorso de’ miei tardi sospiri.« Suvišna riječ »miei« narušava i strukturu endecasillaba i rafinirani momenat nesigurnosti, kada Petrarca namjerno zamagljuje značenje i ostavlja čitaocu da sam dokuči o čijim se uzdasima zapravo radi.

Samo nekih šest godina dijeli Vincijevu verziju ovoga soneta od Wertove. Desetak godina mlađi od Vincija, Giaches (Iaches) de Wert (1535-1596) je svojom prisutnošću u centrima sjeverne Italije, svojom kontrapunktskom vještinom i po ingenioznošću s kojom je prilazio formalnim rješenjima u svojim madrigalima, ostavio daleko dublji trag u muzici svoga vremena. Istina, i Vinci je jedno vrijeme bio cijenjen a o tome svjedoče čak četiri izdanja prve knjige madrigala. Prelaskom u Bergamo, 1568. godine, gdje se zadržao čitavih dvanaest godina, i on se našao u blizini brojnih važnijih centara, ali se usprkos svemu ovome njegov stil tokom druge polovice cinquecenta pokazao onim što je zapravo uvijek i bio: stil solidne kontrapunktske tehnike, bez većeg ulaženja u finese poetskog teksta. Wert je po svemu ovome mnogo bliže duhu svoga vremena: pažljiv prema tekstu ali u isto vrijeme ingeniozan, želeći da iznenadi kakvim originalnim formalnim postupkom ali da ga u isto vrijeme i prikrije kao da samoga sebe stavlja u poziciju pjesnika pa se igra elementima poetskog teksta pokazujući da ga suvereno poznaje i kombinira svoju originalnost sa mogućnostima koje tekst otkriva tek onome tko mu se zna približiti.

Peteroglasni Wertov madrigal »Se la mia vita« ima u početnim taktovima nekih sličnosti sa njegovim kasnijim »Datemi pace, o duri miei pensieri«, ${ }^{4}$ otvarajući se jednim kontrapunktskim tkivom sa nekoliko elemenata, svaki od kojih postaje na svoj način izvor daljnjih melodijskih i formalnih postupaka. Tako, kombinirane dionice soprana i drugog tenora donose jednu liniju koja ocrtava konturu od nekoliko uzlaznih terci: dva isprepletena trozvuka ( $d-f-a, f-a-c)$, koji će poslužiti kao jezgro kasnijeg dugačkog luka jedne harmonske sheme. Početna tri tona u sopranskoj dionici najvjerojatnije skrivaju drugi jedan trik - soggetto cavato - izvodeći visine d-a-e (re-la-mi) iz Petrarkinih riječi »Se la mi(a vita)«, dok je ostatak sopranske linije, pažljivo dijeleći motive prema položaju cezure u Petrarkinu stihu, stisnut u jednu umanjenu kvartu (c-h-a-gis), potencirajući time emotivno značenje fraze »da l'aspro tormento«(Pr. 2).

Više o strukturi Wertova madrigala »Datemi pace« vidi kod Bujić, "Cinquecento Madrigalists«. 
Pr. 2, Wert, „Se la mia vita«, početak Prima parte:

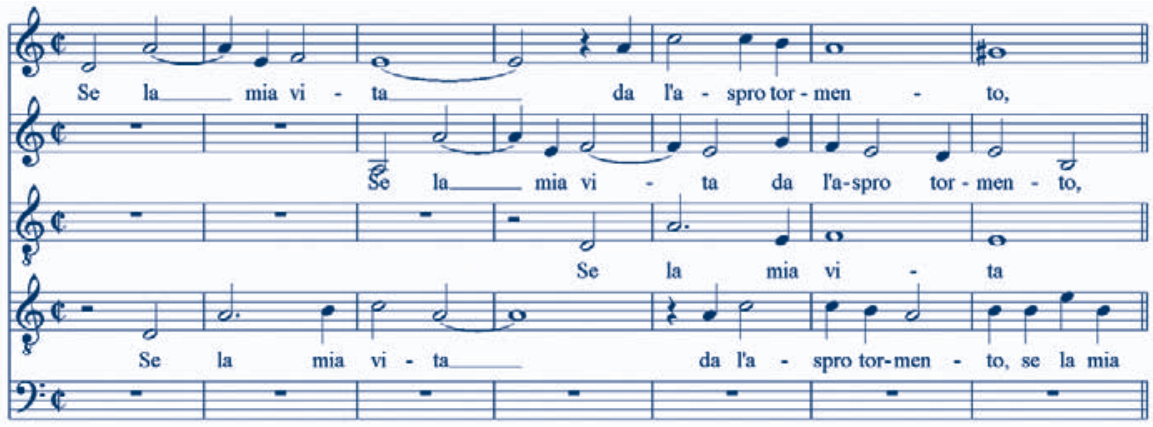

Wert, iako za svoj madrigal nije bio izabrao frigijski način, ipak iskorištava semantičku osobinu frigijskoga motiva silazne kvarte. Turobna i tragična konotacija ovoga motiva jedna je od konstanti ekspresivnog jezika, ne samo Wertove generacije. Osnovni frigijski pomak - $e-d-c-h$ - možemo slijediti od Isaacove »Quis dabit«, pa preko čitavoga šesnaestog stoljeća do kasnoga Monteverdija u »Lamento della ninfa« iz Osme knjige madrigala. Nakon toga ovaj motiv postaje sastavni dio ostinatne figure chaconne, opet vezan za tragični sadržaj (napr. u Didoninoj tužbalici iz Purcellove opere Dido and Aeneas). Wert potencira taj sadržaj, dodatno umanjujući tu kvartu tako da ona sadrži dva a ne samo jedan polustepen. Tako nešto, sa sličnim rezultatom velike emocionalne napetosti, učinio je već bio u generaciji prije Wertove Philippe Verdelot u baladi »Sì lieta e grata morte« i nije isključeno da je Wert poznavao ovu kompoziciju. Lako je pretpostaviti da je on poznavao i Vincijevu verziju "Se la mia vita«, pa je na svoj način varirao Vincijevo uvođenje tona cis, stranoga modusu, kojim je ovaj podcrtao emocionalni sadržaj teksta.

Ipak se Wertova verzija bitno razlikuje od Vincijeve, ne samo po izraženijem ekspresivnome detalju umanjene kvarte, nego po kompozicijskoj vještini kojom taj detalj, pojavivši se kao motiv u početnim taktovima madrigala, preuzima značaj idée fixe. Wert zaključuje prvi dio madrigala naglašavajući ovaj motiv, sada u uzlaznoj formi između cis if, na prilazu kadenci (Pr. 3).

Pr. 3, Wert, „Se la mia vita«, kraj Prima parte:

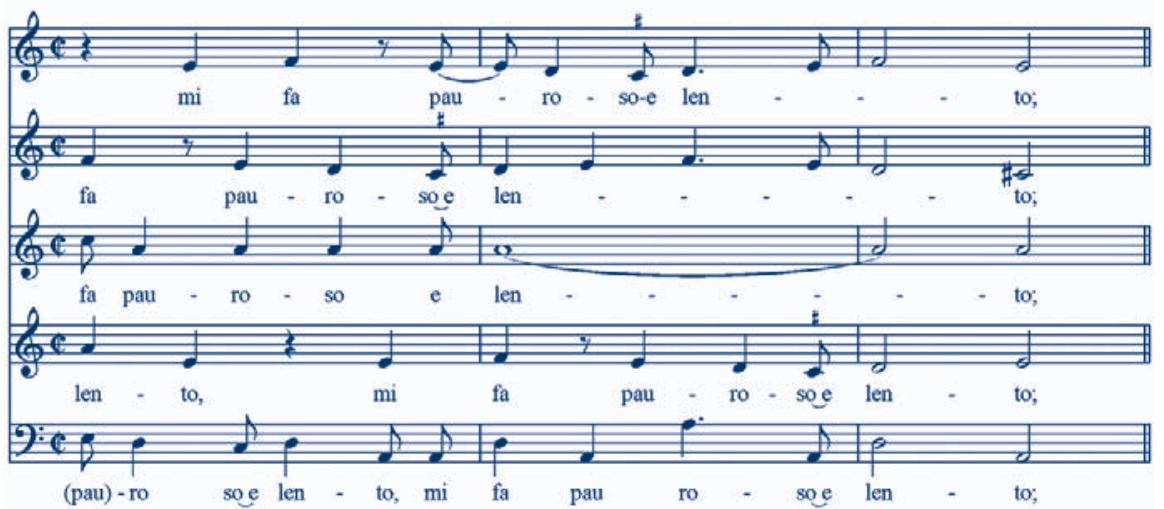


Drugi dio madrigala izbjegava ovaj pomak, ali, kada se slušalac već privikao na njegovo odsustvo, Wert ga ponovo uvodi, u originalnoj silaznoj formi, na početku posljednjeg stiha, »alcun soccorso di tardi sospiri«, i u toku nekih devet završnih taktova predstavlja ga i kao c-h-a-gis i kao sekvencnu varijantu za stupanj niže: b-a-g-fis (Pr. 4).

Pr. 4, Wert, "Se la mia vita", kraj Seconda parte (sopran):

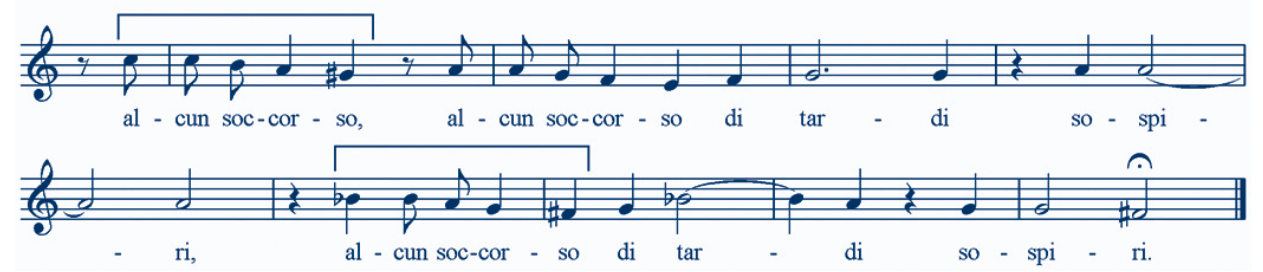

Potvrda da je Wert, kao rafinirani čitalac Petrarke, shvatio i osjetio cjelovitost neprekinutoga retoričarskog toka u sonetu, nalazi se u ovome tematskom detalju koji ujedinjuje čitavu kompoziciju - od početka Prima parte do kraja Seconda parte - potvrđujući da se radi o jednoj jedinoj monološkoj rečenici koja od početka pa do kraja ne gubi svoj intenzitet. Ali ni ovo nije sve jer je Wert uspio uplesti u tkivo madrigala i svojevrsno simboličko tumačenje implikacije Petrarkinog sjetnog razmišljanja o prolasku ljudskoga vijeka.

Raniji madrigalisti, uključujući i Vincijevu generaciju, manje su polagali pažnju sintaktičkim detaljima poezije, često se zadovoljavajući time da se drže kraja jednoga stiha i rimujućih riječi kao indikacije gdje da smjeste kraj jedne muzičke fraze. Zato je u prvi mah začuđujuće da Wert, inače pažljiv čitalac, formira unutarnju kadencnu strukturu madrigala kao da se slijepo drži svakoga jedanaesterca, bez obzira na enjambement, na primjer, na kraju prvoga, trećega ili desetoga stiha. Svaki endecasillabo služi mu kao jasno određena fraza, omogućujući mu da svaku završi sa manje-više izraženom kadencom, pretežno »novoga", harmonskoga tipa sa pomakom u basovoj dionici od kvinte naniže između predzadnjega i zadnjega kadencnog akorda. Tokom čitave Prima parte, ta se kadencna struktura dade svesti na jedan obrazac u kojem su prepoznatljivi koraci terce: prvi stih kadencira na A, drugi na F, treći na A, četvrti na C. Stihovi 5-8 nastavljaju jednom varijantom ove vrste harmonskog »šetanja« između kadencnih stupanjeva, ali je u prvi mah teško vidjeti u ovome neki dublji smisao. Jedino što se nameće kao pomisao jeste da je Wert iskoristio ideju terasastih terci, sugeriranih početnim vokalnim linijama, da ih projicira u harmonski luk, nešto poput procesa kojega je Brahms, sa sličnom ingenioznošću, primijenio u svojoj Trećoj simfoniji nekih tri stotine godina kasnije. Wertova namjera, međutim, postaje nešto jasnijom u Seconda parte. I ovdje se lako opaža česta pojava jasno definiranih kadencnih odmorišta, poklapajući se sa svakim od šest jedanaesteraca koji tvore drugi dio Petrarkinog soneta. Regularnost visina na kojima Wert kadencira otkriva ga kao nenadmašnoga majstora simboličkog načina muzičkog slikanja. Naime, Petrarkin deveti stih (»Amore») kod Werta kadencira na G, deseti (»martiri»), na E, jedanaesti (»'ore«) na C, i tako dalje, uobličavajući u stihovima 9-12 kadencnu strukturu cijele Seconda parte u jedan jedinstveni niz silaznih terci (G-E-C-A-F-D), modificiranih jedino ograničenjima fizičkog opsega ljudskog glasa (Pr. 5). 
Pr. 5, Wert, "Se la mia vita«, Seconda parte, poredak kadenci:

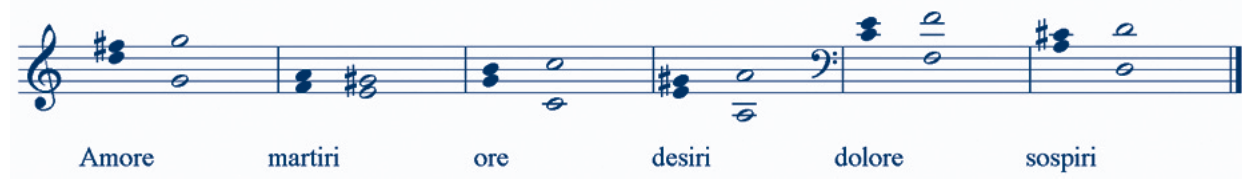

Posljednja strukturalna kadenca (na D), dostignuta pomakom dominante ka tonici zatvara taj niz, a onda se madrigal završava samo jednim plagalnim nizom koji oscilira između trozvuka na G i D, tipičnih za code u kasnijim funkcionalnim harmonskim slogovima. Ako se i nije ovdje otvoreno obratio svima onima koji slušaju izvedbu ovoga madrigala, Wert je najprije pjevačima otkrio dubinsku vezu između Petrarkine sjetne poezije i simboličke harmonske strukture u koju je tu poeziju odjenuo. Niz silaznih terci u redoslijedu kadenci možda je teško čuti, barem kod prvoga slušanja, ali on postaje prepoznatljiv jednom kada izvađač ili slušalac proniknu u tkivo madrigala: onako kako neumitno prolazi vrijeme i ljudski se vijek primiče svome kraju, tako i kadencirajući stupnjevi silaze po ljestvici naizgled bezosjećajnih terci.

O tome da Marenzio predstavlja vrhunac madrigala kasnoga cinquecenta, postoji među muzikolozima već dobro ustaljena suglasnost. Da li iz toga slijedi da je i njegova verzija "Se la mia vita u u nekome smislu bolja i uspjelija od Wertove? Marenzio je već bio madrigalista velike reputacije kada je godine 1588 objavio Primo libro de' madrigali a quattro, cinque e sei voci. Četveroglasni slog je u to vrijeme gubio na popularnosti kod kompozitora koji su stajali u prvome redu novatora u muzičkome stilu i jeziku, a Marenzio se po svoj prilici odlučio za ove različite kombinacije glasova jer je želio pokazati kako se novi harmonski stil, po kojem je on već bio poznat tokom 1580-tih godina, može provesti u praksu bez obzira na broj glasova. Zanimljivo je da je ovo jedina Marenzijeva zbirka koja nikada nije doživjela drugo izdanje, dok su sve ostale njegove zbirke izdavane po nekoliko puta, ne samo u Italiji nego i drugdje. Teško bi bilo protumačiti ovo kao izraz neuspjeha madrigala iz ove zbirke, ali je sigurno da, ograničeni na samo jedno izdanje, ovi madrigali nisu dosegli onu popularnost koju je Marenzio postizao drugim svojim djelima. Kasniji historičari su, međutim, u madrigalima iz ove zbirke vidjeli djela koja po svemu odgovaraju Marenzijevoj uobičajenoj reputaciji, a uz to sadrže i elemente novoga, funkcionalo-harmonskog načina mišljenja. Čini mi se da bi bilo bolje revidirati ovu kritičku pohvalu pa sugerirati da, iako je Marenzio kretao u ovome pravcu, to mu nije uvijek, pa ni u ovome madrigalu, sasvim polazilo od ruke.

Da je Marenzio u svojoj verziji Petrarke imao upravo Wertov madrigal na umu, vidi se po sličnosti njihovih početnih motiva, iako je Marenzio preinačio Wertov početak, služeći se tehnikom inganno: Wertov re-la-mi (d-a-e) kod njega je postao $d$-e-h, odnosno g-a-e, putem miješanja različitih heksakorada (Pr. 6). ${ }^{5}$

\footnotetext{
Inganno (doslovno »obmana") je postupak pri kojemu se od jednoga motiva može napraviti drugi tako da se umjesto jednoga, logički očekivanoga heksakorda, kombiniraju dva ili više. Wertov soggetto cavato pripada jedinstvenome heksakordu na C (naturale), dok Marenzio kombinira re ( $g$ ) iz heksakorda na F (molle), sa la i mi $(a$ i $e$ ) iz heksakorda na C. Inganno su u imitativnim otvaranjima osobito često upotrebljavali kompozitori instrumentalne muzike u ranom sedamnaestom stoljeću (napr. Frescobaldi), ali se korijeni ove tehnike nalaze u vokalnoj muzici posljednje četvrine šesnaestoga stoljeća. U svojoj opsežnoj studiji Marenzijevih madrigala na Petrarkine stihove (Die Petrarca-Vertonungen von Luca Marenzio, Tutzing, 1992) Bernhard Janz pokusao je objasniti Marenzijevu solmizaciju na anakronistički način, uzimajući $s$ iz "Se« kao povod za sol, ne vodeći računa o principu inganno.
} 
Pr. 6, Marenzio, »Se la mia vita", početni taktovi Prima parte:

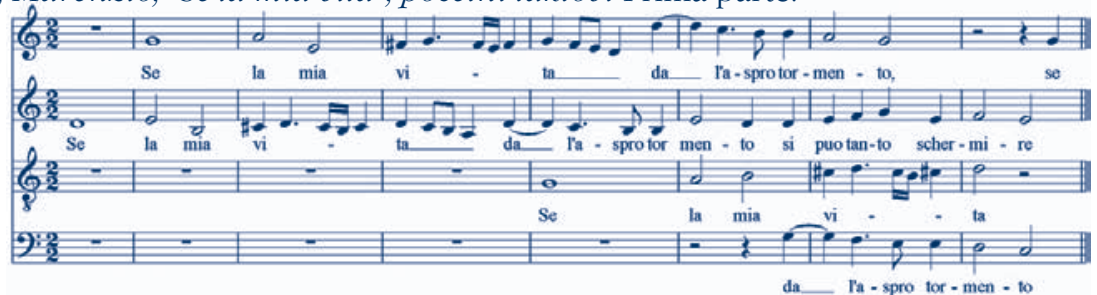

Ostatak Marenzijeve teme pokazuje jasno izraženu kombinaciju dijelova melodije koji ili se drže centra G, ili na čas sugeriraju dominantu, da bi se pomakom sa dominante ka tonici cjelina zakoruzila. Sličan proces, kao da se radi o varijaciji na motive iskorištene na početku, nalazi se na kraju madrigala, slobodno kombinirajući segmente originalne melodije.

Analiza Marenzijeve verzije »Se la mia vita« pokazuje da se je on, umjesto Wertove široko razgranate kadencne strukture, držao jednog suzdržanijeg harmonskog plana. Njegov Gmiksolidijski način, u biti moderni dur, međutim ne pokazuje harmonsku strukturu u kojoj bi dominanta igrala ulogu presudnog alternativnog tonskog centra. U prvome Petrarkinom kvatrenu dominira centar G, a u drugome je osjetan pomak G-C, sa »toniciziranjem "A. Taj proces omogućuje na kraju Prima parte kadencu frigijskoga tipa na E, a u tome načinu počinje i Seconda parte i to vrlo izraženo, jer Marenzio ovdje upotrebljava tradicionalno tkivo imitacije u parovima (tenor + bas, alt + sopran). Već na kraju Petrarkinog jedanaestog stiha (»giorni, et l'hore«), G je učvršćen izrazito modernom kadencom. Slijedi onda jedan zanimljivi dio u kojem se tonalne osobine G-modusa opetovano potvrđuju u višim glasovima, dok im u nižim jedno vrijeme oponira alternativna sugestija C-modusa. Pred kraj, na tekst posljednjeg Petrarkinog stiha, u sopranu se osjeća polariziranje između dominante D i tonike G (Pr. 7).

Pr. 7, Marenzio, "Se la mia vita", kraj Seconda parte:

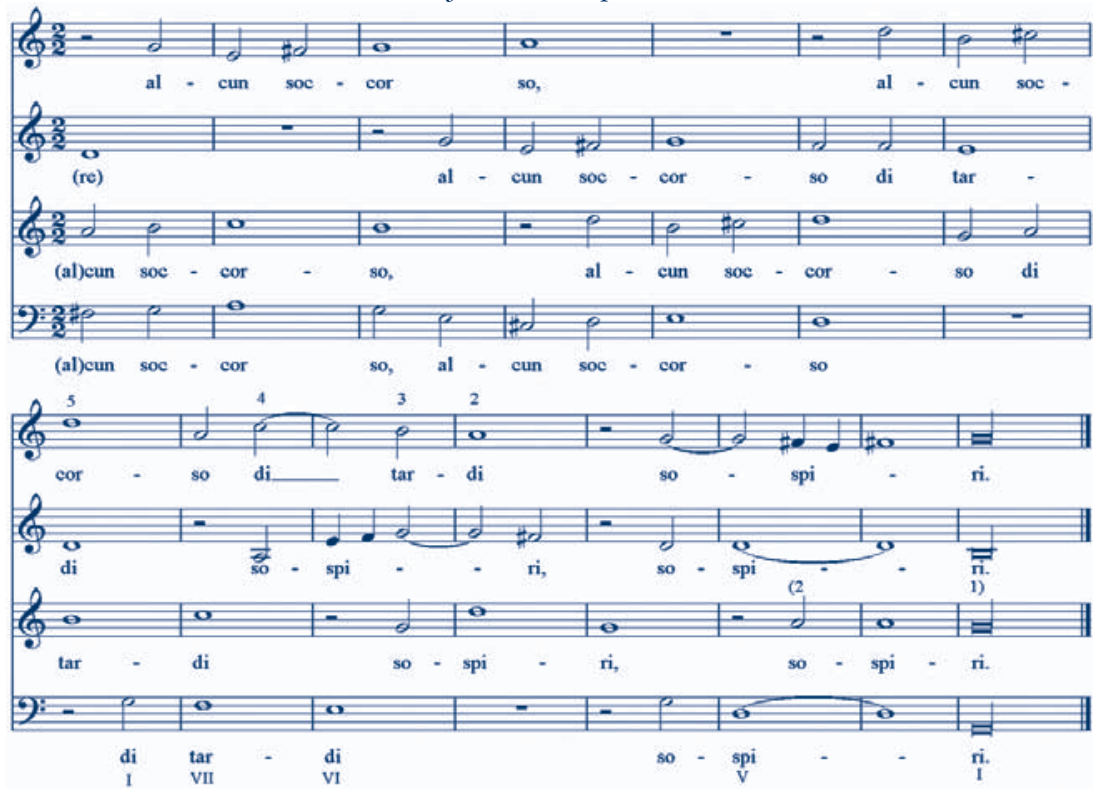


Time ovaj madrigal iz daleka podsjeća na Wertov - u oba slučaja početak i kraj imaju nešto zajedničko jer je Marenzio, neodvisno od detalja harmonske strukture, iskoristio pri kraju madrigala elemente melodijskih pomaka kojima on započinje.

Logika Petrarkine cjelovitosti, ona kvaliteta poetskoga djela koju je Wert pretočio u motivičku i harmonsku shemu, u Marenzijevoj je verziji nekoliko puta dovedena u pitanje. Monološki karakter soneta, kojega su dobro shvatili i Vinci i Wert, u Marenzija je protumačen na svojevrstan način, pri čemu je taj karakter često iznevjeren. Wert je postigao cjelovitost već i svojim polifonim slogom, pažljivo se držeći harmonske punoće u čemu mu je pomogao i njegov peteroglasni stav. Marenzio, čini se, poseže za jednim naoko modernijim idealom zvučne strukture, bez obzira što je taj ideal zapravo neprimjeren Petrarkinim poetskim intencijama. On na mjestima razbija jedinstvo Petrarkinog narativnoga poetskog glasa, pa tako u nekoliko presudnih slučajeva, kod riječi "ch i' veggia per vertù ", "pur mi darà tanta baldanza Amore«, »qua' sono stati gl'anni, e i giorni et l'hore« i »et se 'l tempo è contrario« upotrebljava »vokalnu orkestraciju«, neku vrstu antifonalnog prezentiranja materijala pri čemu nakon jednoga para glasova istu ili sličnu frazu preuzima drugi par (Pr. 8).

Pr. 8, Marenzio, »Se la mia vita", primjer dueta:

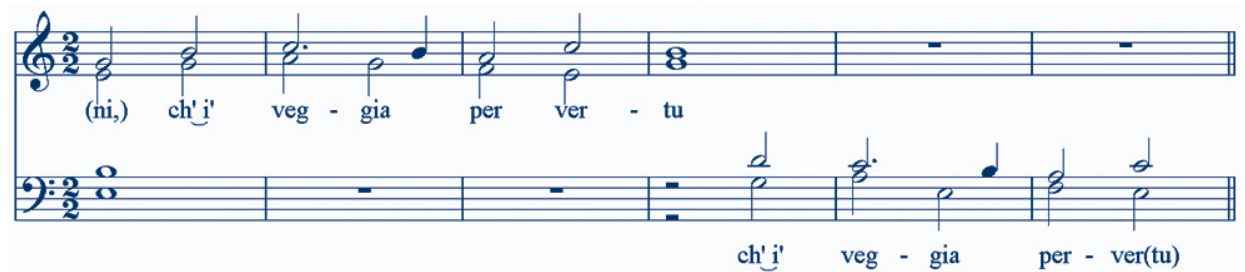

Tim ponavljanjem postiže se, doduše, pjevnost i svim glasovima se omogućava da sudjeluju u melodijskom materijalu, ali se ujedno usporava tok teksta i slabi napetost koja kod Petrarke obuhvaća cijeli sonet.

O Marenzijevom novome stilu pisao je Vincenzo Giustiniani početkom sedamnaestoga stoljeća sa velikim odobravanjem. Po njemu su Marenzio i Ruggiero Giovannelli tokom 1580tih godina uveli jedan novi, ugodni melodijski stil ("nuova aria e grata all'orecchie») koji se odlikovao jednostavnim imitativnim motivima (»fughe«), bez osobite izvještačenosti (»senza straordinario arteficio«). ${ }^{6}$ Ove se osobine zaista i mogu naći u Marenzijevoj verziji »Se la mia vita«, ali upravo ta naklonost prema ljupkosti unosi u njegov madrigal duboku kontradikciju između kontinuiteta kojega zahtijeva Petrarca i neizbježnog slabljenja jedinstva narativnog tona, kojega Marenzijevi nizovi dueta pretvaraju u fragmente. Marenzio je, doduše, na mjestima posegnuo ili za tonskim slikanjem (pomalo predvidljiva melizma na »le ghirlande«) ili za harmonskim naglašavanjem poetskih momenata (iznenadni pomak ka trozvuku e-gis-h na »'argento«, izričito disonantni sklop dis-fis-a-c na "pauroso»), ali upravo zbog toga momentalnog javljanja naglasaka koji jednako brzo ustupaju mjesto običnijem slogu, ovaj postupak gubi na ubjedljivosti i doima se kao mehanička deklaracija modernosti.

Neki muzikolozi, kao napr. Anthony Newcomb, bili su zaintrigirani pojavom "protofunkcionalnog« načina harmonijskog mišljenja kod Marenzia ali su ujedno bili skeptični

6 Vincenzo Giustiniani, Discorsi sulle arti e sui mestieri, ur. Anna Banti. Firenze: Sansoni, 1981, 20-21. 
prema pokušaju da se ovo protumači na deterministički nacin. ${ }^{7}$ Ne radi se o Giustinianijevim pohvalama, nego o identificiranju nastupajućeg funkcionalnog sloga koji će svoju individualnost izraziti tek tokom nadolazećega stoljeća. Newcomb je došao do opreznoga zaključka da ovaj proces nije linearno i predvidljivo evolucioni ali nije ponudio jasniji dokaz o tome. On bi se mogao formulirati ovako: onako kako nailazimo na suprotnost između poetske intencije i muzičkoga tkiva, u pojedninim djelima - kao što je i ovaj madrigal - nailazimo na kontradikciju između funkcionalnog osjećaja koji se kristalizira kroz jasnost melodijskih linija i istovremeno nesigurnog prodiranja funkcionalnoga sloga u vertikalno harmonsko tkivo. Tako pristup kadenci u "Se la mia vita" pokazuje u sopranu jasnu polarizaciju melodijskih regija dominante i tonike, a prilaz tonici ostvaren je sa jasnim pomakom melodijskih stupnjeva 5-4-3-2-1 (Pr. 7). Nemalo iznenađujuće je da je ovaj kadencni pomak ostvaren na harmonski nefunkcionalan način (pomakom I-VII-VIV-I), putem strukturalnog kostura u kojem se kontrapunkt vanjskih glasova dade svesti na niz paralelnih kvinti, iako su one u stvarnome zvučanju izbjegnute vještinom linearnog razmještanja i dijeljenja između kontrapunktskih glasova (Pr. 9).

Pr. 9, Marenzio, „Se la mia vita", strukturni kostur završne kadence:

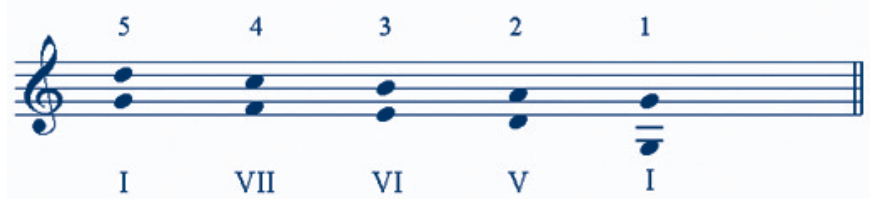

Ovo dovoljno jasno pokazuje Marenzijevu ovisnost ne o proto-funkcionalnome nego o linearnom slogu.

Torquato Tasso, ne znajući ništa o teorijskim implikacijama, naslutio je da je u muzici njegova vremena došlo do jedne promjene. U dijalogu La Cavaletta overo de la poesia toscana (1584) on ju je protumačio na estetski način, tvrdeći da je muzika postala "molle ed effeminata« i nadao se da će Striggio, Wert i Luzzaschi biti oni koji će je vratiti prijašnjoj ozbiljnosti ("a quella gravità da la quale traviando è spesso traboccata in parte di cui è più bello tacere che 'l ragionare «). ${ }^{8}$ La Cavaletta je napisana nekoliko godina prije pojave Marenzijevog madrigala pa ga Tasso nije ovdje mogao imati na umu. Uz to, uzdajući se u Striggia, Werta i Luzzaschija, potvrdio je da su mu oni bili bliži jer su pripadali njegovome sjevernom kulturnome krugu, dok mu se južna, rimska muzika činila dalekom i odbojnom. Međutim, već njegovo razmišljanje o uzrocima promjene pokazuje da su i on i drugi u njegovoj blizini shvaćali odnos poezije i muzike na jedan kritički način, iako Tasso nije raspolagao adekvatnim teorijskim znanjem niti kritičkim vokabularom kojim bi mogao rasvijetliti taj problem.

Anthony Newcomb je opazio da je i Marenzio nakon ovoga perioda promijenio svoj stil i da je tokom posljednje decenije stoljeća njegov odnos prema poeziji postao produbljeniji. I ovdje bi bilo umjesno izraziti jednu malu rezervu. Taj odnos jeste postao

Anthony Newcomb, "Marenzio and the 'Nuova aria e grata all'orecchie'«. U Music in the Mirror. Reflections on the History of Music Theory and Literature for the 21st Century, ur. Andreas Giger i Thomas J. Mathiesen. Lincoln-London: University of Nebraska Press, 2002, 61-75.

8 Torquato Tasso, La Cavaletta overo de la poesia toscana, $\mathbb{\$}$ 180. Citirano po T. Tasso, Dialoghi, edizione critica a cura di Ezio Raimondi. Firenze: Sansoni, 1958. 
produbljeniji, ali više na maniristički način, potencirajući zapravo one iste momente iznenađenja i naglog skretanja u neki ekspresivni detalj, onako kako je to bio učinio i u »Se la mia vita«. Istina, potkraj stoljeća maniristički momenti iznenađenja su bili prihvaćeni kao izraz novoga ukusa ali ostaje otvoreno pitanje da li bi Tasso bio podržao Luzzaschijeve eksperimente u ovome pravcu i da li bi i dalje držao da je on taj koji će muziku vratiti na pravi put.

Nedvojbeno je u svemu ovome da se je ponešto od Marenzijevog repertoara iz 1580tih godina našlo u procjepu između različitih stilskih faza - Marenzio je na jedan način želio biti »moderan" pa je prihvatio kriterij pjevnosti, ali kada se je ekspresivni ideal opet počeo mijenjati 1590-tih godina, ovaj je stil brzo izgubio nešto od svoje privlačnosti. Ovim se možda može objasniti činjenica da Marenzijava zbirka iz 1588. godine nije nikada doživjela drugo izdanje: stilski zaokreti u tim godinama bili su previše nagli da bi zbirci osigurali dužu popularnost, a kod Giustinijanija se možda radilo jednostavno o dozi nostalgije s kojom se negdje u trećoj deceniji seicenta prisjećao svoje mladosti i muzike koju je 1580-tih godina slušao u Rimu.

Odavno se je već uvriježilo stanovište da muzikolozi ne smiju pokazivati izričitu privrženost jednima a kritički stavljati po strani druga djela iz davnije prošlosti - njihova objektivnost je tobože ovim dovedena u pitanje. Usuđujem se riskirati reputaciju profesionalne nepristrasnosti pa se između ove trojice kompozitora odlučiti za Werta kao onoga kojemu je uspjelo stvoriti pravo remek-djelo. Jedino se u procesu izvedbe može osjetiti intenzitet i duboka veza između poezije i muzike, a ta je daleko izraženija kod Werta nego kod ponešto opreznoga i korektnoga Vincija ili kod Marenzija, čiji madrigalski slog u ovome slučaju trpi od iznenadnih promjena polifonog tkiva i slabi kroz šablonske primjene vokalnih dueta. Wertov »sospiro« je, jednostavno rečeno, dublji od ostalih. 